\title{
Activation of D1 and D2 Dopamine Receptors Increases the Activity of the Somatostatin Receptor-Effector System in the Rat Frontoparietal Cortex
}

\author{
Rosa M. Izquierdo-Claros, María del Carmen Boyano-Adánez, and \\ Eduardo Arilla-Ferreiro ${ }^{\star}$ \\ Departamento de Bioquímica y Biología Molecular, Facultad de Medicina, Universidad de Alcalá, \\ Alcalá de Henares, Madrid, Spain
}

The role of dopamine D1 and D2 receptor subtypes in the regulation, in vivo, of the somatostatin (SRIF) receptoreffector system in rat frontoparietal cortex was investigated. The D1-receptor agonist SKF $38393(4 \mathrm{mg} / \mathrm{kg})$ or the D2-receptor agonist bromocriptine (2 mg/ $\mathrm{kg})$, administered intraperitoneally to rats, increased the number of SRIF receptors without altering the affinity constant, an effect antagonized by both SCH $23390(0.25 \mathrm{mg} / \mathrm{kg})$ and raclopride $(5 \mathrm{mg} / \mathrm{kg}), \mathrm{D} 1$ and D2 receptor antagonists, respectively. These antagonists alone had no effect on $\left[{ }^{125} \mathrm{I}\right] \mathrm{Tyr}^{3}$ octreotide binding to its receptors. No change in binding was detected when the dopamine agonists were added in vitro. Basal adenylyl cyclase (AC) activity was increased by SKF 38393 treatment and decreased by bromocriptine. Octreotide (SMS 201-995)-mediated inhibition of basal and forskolin-stimulated AC was increased by SKF 38393 or bromocriptine treatment. In frontoparietal cortical slices, basal inositol-1,4,5triphosphate $\left(\mathrm{IP}_{3}\right)$ levels were decreased by bromocriptine treatment but were unaffected by SKF 38393. SMS 201-995 increased the $\mathrm{IP}_{3}$ accumulation in control, SKF 38393-, and bromocriptine-treated rats. Insofar as SRIF and dopamine appear to be involved in motor regulation and could well modulate somatosensory functions in frontal and parietal cortex, respectively, heterologous receptor regulation may have important repercussions regarding the control exerted by these neurotransmitters on frontal and parietal cortical function in the intact animal. J. Neurosci. Res. 62:91-98, 2000.

๑) 2000 Wiley-Liss, Inc.

Key words: SKF 38393; bromocriptine; SCH 23390; raclopride; somatostatin receptor; adenylyl cyclase; inositol-1,4,5-triphosphate; rat; frontoparietal cortex

Several studies have indicated selective localization of somatostatin (SRIF)-like immunoreactivity in deep cortical layers (Finley et al., 1981; Hendry et al., 1984; Johansson et al., 1984). Cerebral cortical membranes contain one of the largest SRIF receptor concentrations (Sri- kant and Patel, 1981; Reubi and Maurer, 1985; Krantic et al., 1990). The effects of SRIF on the central nervous system (CNS) are mediated by G-protein-coupled receptors (Law et al., 1991). Following the cloning of the genes encoding for at least five SRIF receptor subtypes, labelled SSTR1-5 (Hoyer et al., 1995), it became evident that the SS1/SRIF-1 class comprises SSTR2, SSTR 3, and SSTR 5 receptors, whereas the SS2/SRIF-2 class consists of SSTR1 and SSTR4 receptors (Brunns et al., 1995). All these receptors mediate inhibition of adenylyl cyclase (AC) activity (Patel, 1999) whereas SSTR2 and SSTR5 also couple to phospholipase C (PLC) in CNS. The deeper layers of cortical areas, rich in SRIF and its receptors, have been shown to contain an innervation of dopamine (DA)positive nerve terminals originating from the ventral midbrain tegmentum (Descarries et al., 1987). The dopaminergic input to the frontal and parietal cortices plays an important role in sensorimotor functions (Gaspar et al., 1995), such as SRIF (Welker, 1971; Finley et al., 1981; Epelbaum et al., 1982). DA exerts its action via dopamine D1-like (D1 and D5) and D2-like (D2, D3, and D4) receptors, although the neural circuits involved are not completely understood (Civelli et al., 1993). Several studies suggest that SRIF and DA receptors are colocalized on neuronal subgroups (Chneiweiss et al., 1985a). Behavioral studies have shown the importance of an intact somatostatinergic system in the full expression of DA-mediated behaviors (Lee et al., 1988). Although interactions between SRIF and dopaminergic neurons are well documented (Pérez-Oso et al., 1989; Salin et al., 1990; Shog-

Contract grant sponsor: Dirección General de Investigación Científica y Técnica; Contract grant number: PM95-0041; Contract grant sponsor: Universidad de Alcalá of Spain; Contract grant number: E007/97.

^Correspondence to: Dr. Eduardo Arilla-Ferreiro, Departamento de Bioquímica y Biología Molecular, Facultad de Medicina, Universidad de Alcalá, E-28871 Alcalá de Henares, Madrid, Spain.

E-mail: bqmob@bioqui.alcala.es

Received 15 September 1999; Revised 16 April 2000; Accepted 31 May 2000 
monian and Chesselet, 1991; Engber et al., 1992; De los Frailes et al., 1993; Pérez-Oso and Arilla, 1993; Rodríguez-Sánchez et al., 1997), there are no reports concerning the influence of D1 and D2 dopamine receptors on the SRIF receptor-effector system located in the cerebral cortex.

Because the deeper cortical layers are enriched in SS1/SRIF1 receptor sites (Krantic et al., 1990) and the stable SRIF octapeptide SMS 201-995 (octreotide) is selective for the SS1/SRIF1 site (Krantic et al., 1992; Hoyer et al., 1994), we have used octreotide and its tyrosine analogue, code named SDZ 204-090, to study the effect of SKF 38393, a D1-receptor agonist, and bromocriptine, a D2-receptor agonist, on the specific binding of $\left.{ }^{125} \mathrm{I}\right] \mathrm{Tyr}^{3}$ octreotide to its receptors and on the ability of SMS 201-995 to inhibit basal and forskolin (FK)stimulated AC activity in rat frontoparietal cortical membranes. In addition, the effect of these compounds on SMS 201-995-stimulated inositol 1,4,5-triphosphate $\left(\mathrm{IP}_{3}\right)$ accumulation in the rat frontoparietal cortex was examinated. The effects of pretreatment with the D1-receptor antagonist, SCH 23390, or the D2-receptor antagonist, raclopride, on the above-cited parameters were also evaluated.

\section{MATERIALS AND METHODS}

\section{Materials}

The peptide SMS 201-995 and its tyrosine analogue SDZ 204-090 were kindly donated by Sandoz (Basel, Switzerland); carrier-free $\mathrm{Na}^{125} \mathrm{I}$ (IMS $300 ; 100 \mathrm{mCi} / \mathrm{ml}$ ) was purchased from the Radiochemical Centre (Amersham, U.K.); SKF 38393 and SCH 23390 were purchased from Research Biochemicals Inc. (Natick, MA); raclopride was kindly donated by Astra Ifesa (Barcelona, Spain); bromocriptine, bacitracin, BSA, forskolin, phenylmethylsulphonyl fluoride, GTP, and 3-isobutyl-1methylxanthine were purchased from Sigma (St. Louis, MO); $\mathrm{IP}_{3}$ and inositol-1,2,3,4,5,6-hexaphosphate (IP 6 ) were from Calbiochem (San Diego, CA); $\left[{ }^{3} \mathrm{H}\right] \mathrm{IP}{ }_{3}$ and $\left[{ }^{3} \mathrm{H}\right]$ cAMP were purchased from DuPont (Boston, MA). All other reagents were of the highest purity commercially available.

\section{Experimental Animals}

All experimental procedures conform to the guidelines established by the Animal Care and Use Committee of our University and were accordingly approved prior to implementation. The animals used in this study were male Wistar rats with an average weight of 200-250 g. Rats were maintained on a 12-hr light-dark cycle (lights on 07:00-19:00 hr) and allowed free access to food. The rats were injected intraperitoneally (i.p.) with $4 \mathrm{mg} / \mathrm{kg}$ of SKF 38393 dissolved in saline or $2 \mathrm{mg} / \mathrm{kg}$ of bromocriptine dissolved in $0.5 \mathrm{ml}$ ethanol $70 \%-0.14 \mathrm{M} \mathrm{NaCl}$ $(1: 1.5 \mathrm{v} / \mathrm{v})$. In other experimental groups, SCH $23390(0.25 \mathrm{mg} /$ $\mathrm{kg}$, i.p.) or raclopride $(5 \mathrm{mg} / \mathrm{kg}$, i.p.), dissolved in saline, was administered $30 \mathrm{~min}$ before their corresponding agonist, SKF 38393 (4 mg/kg, i.p.) or bromocriptine (2 mg/kg, i.p.), respectively. A third group of animals was injected i.p. with $0.25 \mathrm{mg} / \mathrm{kg} \mathrm{SCH} 23390$ or $5 \mathrm{mg} / \mathrm{kg}$ raclopride. Drug doses were selected according to the effective doses reported in previous studies (Augood et al., 1991; Rodríguez-Sánchez et al.,
1997). Control animals selected for each group were injected with equivalent volumes of the corresponding vehicle. Rats were sacrificed by decapitation $3 \mathrm{hr}$ after the last drug injection (Engber et al., 1992). The brain was rapidly removed, and the frontoparietal cortex was dissected over ice as previously outlined (Glowinski and Iversen, 1966).

\section{Iodination of SDZ 204-090}

The stable SRIF analogue SDZ 204-090, which has previously been demonstrated to bind specifically to SRIF receptors with high affinity (Reubi, 1985), was radiodinated according to a technique described for other SRIF-related peptides (Antoniotti et al., 1984). Briefly, $10 \mu \mathrm{l}$ of a $\mathrm{Na}^{125} \mathrm{I}$ solution $(1 \mathrm{mCi})$ were added to $10 \mu \mathrm{g}$ of SDZ 204-090 dissolved in $50 \mu \mathrm{l}$ of a $0.25 \mathrm{M}$ sodium phosphate buffer, $\mathrm{pH}$ 7.5. Subsequently, five additions of $5 \mu \mathrm{l}$ of chloramine- $\mathrm{T}(0.5 \mu \mathrm{g} / \mu \mathrm{l}$ in water) were carried out, with $10 \mathrm{sec}$ intervals between each addition. Finally, $120 \mu \mathrm{l}$ of a tyrosine solution $(2 \mu \mathrm{g} / \mu \mathrm{l}$ in phosphate buffer $0.5 \mathrm{M} / \mathrm{NaOH} 0.2 \mathrm{M}$ ) were added. The mixture was loaded onto a Bondapak C18 column $(30 \times 0.39 \mathrm{~cm}$ i.d. $)$, and, with a Waters Associates liquid chromatograph, the tracer was eluted at a flow of $1 \mathrm{ml} / \mathrm{min}$ in a preprogrammed nonlinear gradient rising from $20 \%$ to $80 \%(\mathrm{v} / \mathrm{v})$ acetonitrile in $0.25 \mathrm{M}$ triethylammonium phosphate, $\mathrm{pH} 3.5$, in $40 \mathrm{~min}$. The tracer was eluted after $15 \mathrm{~min}$. Radioactivity in the fractions containing the tracer was found to be $900 \mathrm{Ci} / \mathrm{mmol}$.

\section{Binding Assay}

Rat frontoparietal cortical membranes were prepared as previously described (Reubi, 1985). Membrane protein was quantified by a technique previously described (Lowry et al., 1951), using BSA as a standard. Specific SMS 201-995 binding was measured according to a modified method (Czernik and Petrack, 1983). Briefly, frontoparietal cortical membranes $(0.036$ $\mathrm{mg}$ protein $/ \mathrm{ml}$ ) were incubated in $250 \mu \mathrm{l}$ of a medium containing $50 \mathrm{mM}$ Tris- $\mathrm{HCl}$ buffer, $\mathrm{pH} 7.5,5 \mathrm{mM} \mathrm{MgCl}, 0.2 \%$ $(\mathrm{w} / \mathrm{v}) \mathrm{BSA}$, and $0.1 \mathrm{mg} / \mathrm{ml}$ bacitracin, with $200 \mathrm{pM}\left[{ }^{125} \mathrm{I}\right] \mathrm{Tyr}^{3}$ octreotide in either the absence or the presence of $0.01-100 \mathrm{nM}$ of SMS 201-995. After incubation for $90 \mathrm{~min}$ at $25^{\circ} \mathrm{C}$, the free radioligand was separated from the bound radioligand by centrifugation at $11,000 \mathrm{~g}$ for $2 \mathrm{~min}$, and the resultant pellet was counted for radioactivity in a Kontron $\gamma$-counter. Nonspecific binding was obtained from the amount of radioactivity bound in the presence of $10^{-7} \mathrm{M}$ unlabelled SMS 201-995 and represented $20 \%$ of the binding observed in the absence of unlabelled peptide. This nonspecific component was subtracted from the total bound radioactivity to obtain the corresponding specific binding.

\section{Adenylyl Cyclase Assay}

AC activity was measured as previously reported (Houslay et al., 1976), with minor modifications. Briefly, frontoparietal cortical membranes $(0.036 \mathrm{mg} / \mathrm{ml})$ were incubated with $1.5 \mathrm{mM}$ ATP, $5 \mathrm{mM} \mathrm{MgSO}$, $10 \mu \mathrm{M}$ GTP, an ATPregenerating system $(7.5 \mathrm{mg} / \mathrm{ml}$ creatine phosphate and $1 \mathrm{mg} / \mathrm{ml}$ creatine kinase), $1 \mathrm{mM}$ 3-isobutyl-1-methylxanthine, $0.1 \mathrm{mM}$ phenylmethylsulphonyl fluoride, $1 \mathrm{mg} / \mathrm{ml}$ bacitracin, $1 \mathrm{mM}$ EDTA, and test substances $\left(10^{-5} \mathrm{M}\right.$ SMS $201-995$ or $10^{-5} \mathrm{M}$ FK) in $0.1 \mathrm{ml}$ of $0.025 \mathrm{M}$ triethanolamine/ $\mathrm{HCl}$ buffer, $\mathrm{pH}$ 7.4. 
After a $15 \mathrm{~min}$ incubation at $30^{\circ} \mathrm{C}$, the reaction was stopped by heating the mixture for $3 \mathrm{~min}$. After getting it cool, $0.2 \mathrm{ml}$ of an alumina slurry $(0.75 \mathrm{~g} / \mathrm{ml}$ in triethanolamine/ $\mathrm{HCl}$ buffer, $\mathrm{pH}$ 7.4) were added, and the resulting suspension was centrifuged at $3,000 \mathrm{~g}$. The supernatant was removed to the cAMP assay as previously described (Gilman, 1970).

\section{IP $_{3}$ Analyses}

Cross-chopped frontoparietal cortical slices $(250 \times 250 \mu \mathrm{m})$ were prepared from male Wistar rats (200-250 g) and preincubated for $45 \mathrm{~min}$ at $37^{\circ} \mathrm{C}$ in Krebs bicarbonate buffer $(118 \mathrm{mM}$ $\mathrm{NaCl}, 4.7 \mathrm{mM} \mathrm{KCl}, 1.3 \mathrm{mM} \mathrm{CaCl}_{2}, 1.2 \mathrm{mM} \mathrm{MgSO}_{4}, 25 \mathrm{mM}$ $\mathrm{NaHCO}_{3}, 11.7 \mathrm{mM}$ glucose, $10 \mathrm{mM}$ HEPES), pH 7.4, saturated with $\mathrm{O}_{2} / \mathrm{CO}_{2}(95 / 5 \%)$, with buffer replacement and gassing every $15 \mathrm{~min}$ (Challiss et al., 1988). Slices were allowed to sediment, and $50 \mu$ l of packed slices were added to tubes containing $200 \mu \mathrm{l}$ of Krebs buffer and $20 \mu \mathrm{l}$ of $1.5 \mathrm{mM} \mathrm{LiCl}$. The samples were gassed regularly, capped, and incubated. SMS $201-995\left(10^{-7} \mathrm{M}\right)$ in a volume of $30 \mu \mathrm{l}$ was subsequently added to these tubes. Incubation was terminated by addition of $500 \mu \mathrm{l}$ of $0.5 \mathrm{M}$ trichloroacetic acid (TCA). Acidified samples were left on ice for $15 \mathrm{~min}$ and subsequently centrifuged for $15 \mathrm{~min}$ at $1,800 \mathrm{~g}$. To remove TCA, the supernatants were washed five times with $1.25 \mathrm{ml}$ of water-saturated diethyl ether, and, finally, $200 \mu \mathrm{l}$ of $50 \mathrm{mM}$ Tris- $\mathrm{HCl}, \mathrm{pH} \mathrm{8.4,} \mathrm{were} \mathrm{added.} \mathrm{The} \mathrm{protein}$ concentration in the tissue pellets was determined as previously described (Lowry et al., 1951).

The specific binding of $\left[{ }^{3} \mathrm{H}\right] \mathrm{IP}_{3}$ to a preparation of bovine cerebellum membranes was used as a radioreceptor assay to determine the $\mathrm{IP}_{3}$ concentration in these slices, according to the method previously described (Bredt et al., 1989). Bovine cerebellar membranes were prepared by homogenizing bovine cerebella in a cold buffer A (50 mM Tris-HCl, $1 \mathrm{mM}$ EDTA and $1 \mathrm{mM}$ 2-mercaptoethanol), $\mathrm{pH} 7.7$, to obtain a protein concentration of $4 \mathrm{mg} / \mathrm{ml}$ (Challiss et al., 1988). These membranes (50 $\mu \mathrm{g} /$ tube) were added to Eppendorf tubes containing $25 \mu \mathrm{l}$ of $\left[{ }^{3} \mathrm{H}\right] \mathrm{IP}_{3}(5 \mathrm{nCi} /$ tube $)$ and $50 \mu \mathrm{l}$ of unknown or standard samples containing $\mathrm{IP}_{3}(0.005 \mu \mathrm{M}-5 \mu \mathrm{M}$ in buffer $\mathrm{A}, \mathrm{pH} 8.6)$ or $\mathrm{IP}_{6}(1 \% \mathrm{w} / \mathrm{v}$ in buffer $\mathrm{A}, \mathrm{pH} 8.6)$ to define nonspecific binding. All tubes were incubated for $10 \mathrm{~min}$ at $4^{\circ} \mathrm{C}$. Separation of bound and free $\mathrm{IP}_{3}$ was achieved by centrifugation at $10,000 \mathrm{~g}$ for $5 \mathrm{~min}$. After aspiration of the supernatant, $50 \mu \mathrm{l}$ of $0.15 \mathrm{M}$ $\mathrm{NaOH}$ were added to each tube, and the pellet was dissolved by shaking. The radioactivity was determined by liquid scintillation spectrometry. The $\mathrm{IP}_{3}$ content was determined by interpolating the inhibition of $\left[{ }^{3} \mathrm{H}\right] \mathrm{IP}_{3}$ binding on a calibration curve with known amounts of $\mathrm{IP}_{3}$. Nonspecific binding was $13 \%$ of the total binding.

\section{Data Analysis}

The computer program LIGAND (Munson and Rodbard, 1980) was used to analyze the binding data. The use of this program enabled us to select receptor models that best fit a given set of binding data. The same program was also used to present data in the form of Scatchard plots (Scatchard, 1949) and to compute values for receptor affinity (Kd) and density (Bmax) that best fit the sets of binding data for each rat. Statistical comparisons of all the data were carried out by one-way analysis of variance (ANOVA) and the Student's Newman-Keuls test.

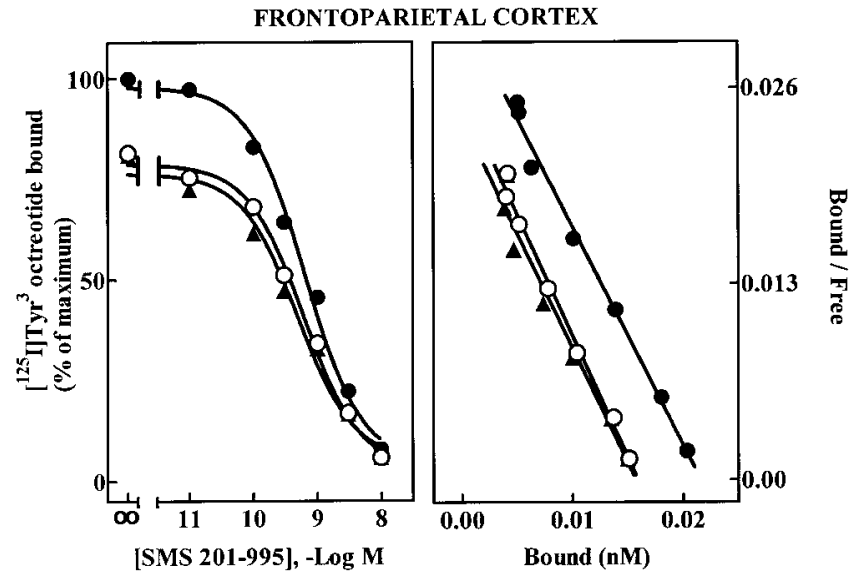

Fig. 1. Binding of $\left[{ }^{125} \mathrm{I}\right] \mathrm{Tyr}^{3}$ octreotide to rat frontoparietal cortical membranes. Left: Displacement of $\left[{ }^{125} \mathrm{I}\right] \mathrm{Tyr}^{3}$ octreotide by increasing concentrations of unlabelled SMS 201-995 to frontoparietal cortical membranes. Specific binding was computed as described in Materials and Methods. Membranes $(0.036 \mathrm{mg}$ protein $/ \mathrm{ml})$ were incubated for $90 \mathrm{~min}$ at $25^{\circ} \mathrm{C}$ in the presence of $\left.200 \mathrm{pM}{ }^{125} \mathrm{I}\right] \mathrm{Tyr}^{3}$ octreotide and increasing concentrations of SMS 201-995. Points correspond to values for the animals in the control group pool (open circles; $\mathrm{n}=5$ ), the SKF 38393 ( $4 \mathrm{mg} / \mathrm{kg}$, i.p.)-treated group (solid circles; $\mathrm{n}=5$ ), and the SCH 23390 (0.25 mg/kg, i.p.) plus SKF 38393 (4 mg/kg, i.p.)-treated group (triangles; $n=5$ ). Each point is the mean of five separate experiments, each performed in duplicate. In the control group, the data are values of a pool of the control groups, because Bmax and $\mathrm{Kd}$ values of the controls were not affected by the vehicle. Right: Scatchard analysis of the binding data.

Means among groups were considered significantly different when $P$ values were $<0.05$. Each experiment was performed in duplicate.

\section{RESULTS}

Stoichiometric experiments were performed on rat frontoparietal cortical membranes using a fixed concentration of $\left[{ }^{125} \mathrm{I}\right] \mathrm{Tyr}^{3}$ octreotide and increasing doses of unlabelled SMS $201-995$ at $25^{\circ} \mathrm{C}$ for $90 \mathrm{~min}$. The competition binding curves are shown in Figures 1 and 2 . The corresponding Scatchard analysis was linear and essentially parallel (Figs. 1, 2, right panel). Interpretation of these data with the LIGAND computer program (Munson and Rodbard, 1980) resulted in the best fit for a model with one type of SRIF receptor. Frontoparietal cortical membranes from SKF 38393- or bromocriptine-treated rats exhibited significant increases in the maximum SRIF binding capacity compared to controls. However, the corresponding $\mathrm{Kd}$ values remained unchanged after treatment. Under specified conditions, the effect of the D1 agonist was similar to that of the D2 agonist (Tables I, II). Pretreatment with SCH 23390 or raclopride completely blocked the SKF 38393- or bromocriptine-induced changes in the number of SMS 201-995 receptors, respectively (Figs. 1, 2, Tables I, II). The administration of SCH 23390 or raclopride alone did not produce any changes in the $\left.{ }^{125} \mathrm{I}\right] \mathrm{Tyr}^{3}$ octreotide binding in frontoparietal cortical membranes. The in 


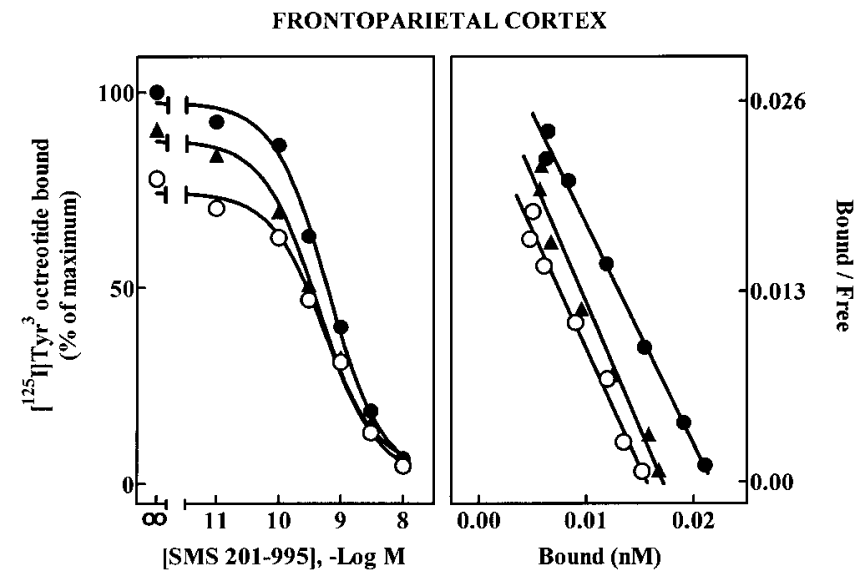

Fig. 2. Binding of $\left[{ }^{125} \mathrm{I}\right] \mathrm{Tyr}^{3}$ octreotide to rat frontoparietal cortical membranes. Left: Displacement of $\left[{ }^{125} \mathrm{I}\right] \mathrm{Tyr}^{3}$ octreotide by increasing concentrations of unlabelled SMS 201-995 to frontoparietal cortical membranes. Specific binding was computed as described in Materials and Methods. Membranes $(0.036 \mathrm{mg}$ of protein $/ \mathrm{ml})$ were incubated for $90 \mathrm{~min}$ at $25^{\circ} \mathrm{C}$ in the presence of $200 \mathrm{pM}\left[{ }^{125} \mathrm{I}\right] \mathrm{Tyr}^{3}$ octreotide and increasing concentrations of SMS 201-995. Points correspond to values for the animals in the control group pool (open circles; $n=5$ ), the bromocriptine ( $2 \mathrm{mg} / \mathrm{kg}$, i.p.)-treated group (solid circles; $\mathrm{n}=5$ ) and the raclopride $(5 \mathrm{mg} / \mathrm{kg}$, i.p.) plus bromocriptine $(2 \mathrm{mg} / \mathrm{kg}$, i.p.)treated group (triangles; $\mathrm{n}=5$ ). Each point is the mean of five separate experiments, each performed in duplicate. In the control group, the data are values of a pool of the control groups, because Bmax and $\mathrm{Kd}$ values of the controls were not affected by the vehicle. Right: Scatchard analysis of the binding data.

TABLE I. Effect of SKF 38393 (4 mg/kg, i.p.), SCH 23390 (0.25 mg/kg, i.p.), or SCH 23390 Plus SKF 38393 on Equilibrium Parameters for $\left[{ }^{125} \mathrm{I}\right] \mathrm{Tyr}^{3}$ Octreotide Binding to Frontoparietal Cortical Membranes ${ }^{\dagger}$

\begin{tabular}{llc}
\hline Group & \multicolumn{1}{c}{ Bmax } & Kd \\
\hline Control & $443 \pm 5$ & $0.60 \pm 0.02$ \\
SKF 38393 & $601 \pm 24 \star \star \star$ & $0.67 \pm 0.03$ \\
SCH 23390 plus SKF 38393 & $439 \pm 5$ & $0.63 \pm 0.04$ \\
SCH 23390 & $487 \pm 21$ & $0.65 \pm 0.03$ \\
\hline
\end{tabular}

${ }^{\dagger}$ Binding parameters were calculated from Scatchard plots by linear regression. Units for Bmax are fmol of SMS 201-995 bound/mg protein and units for $\mathrm{Kd}$ are $\mathrm{nM}$. Data are the mean \pm SEM values of five separate experiments, each performed in duplicate.

$\star \star \star P<0.001$ vs. control.

vitro addition of SKF 38393 or bromocriptine to the incubation medium at the time of the binding assay had no effect on frontoparietal cortical SRIF receptors (data not shown). The signaling pathways coupled to SRIF receptors were evidenced by the ability of SMS 201-995 to inhibit AC activity and to stimulate accumulation of $\mathrm{IP}_{3}$. We examined the inhibitory effect of increasing concentrations of SMS 201-995 on basal and FK $\left(10^{-5} \mathrm{M}\right)$ stimulated AC activity in frontoparietal cortical membranes of control rats. The somatostatinergic inhibition of both basal and FK-stimulated AC activity was significant
TABLE II. Effect of Bromocriptine ( $2 \mathrm{mg} / \mathrm{kg}$, i.p.), Raclopride (5 mg/kg, i.p.), or Raclopride Plus Bromocriptine on Equilibrium Parameters for $\left[{ }^{125} \mathrm{I}\right] \mathrm{Tyr}^{3}$ Octreotide Binding to Frontoparietal Cortical Membranes ${ }^{\dagger}$

\begin{tabular}{llc}
\hline Group & \multicolumn{1}{c}{ Bmax } & $\mathrm{Kd}$ \\
\hline Control & $441 \pm 16$ & $0.46 \pm 0.01$ \\
Bromocriptine & $610 \pm 7 \star \star$ & $0.49 \pm 0.01$ \\
Raclopride plus bromocriptine & $484 \pm 16$ & $0.42 \pm 0.02$ \\
Raclopride & $495 \pm 25$ & $0.44 \pm 0.01$ \\
\hline
\end{tabular}

${ }^{\dagger}$ Binding parameters were calculated from Scatchard plots by linear regression. Units for Bmax are fmol of SMS 201-995 bound/mg protein and units for Kd are nM. Data are the mean \pm SEM values of five separate experiments, each performed in duplicate. $\star \star P<0.01$ vs. control

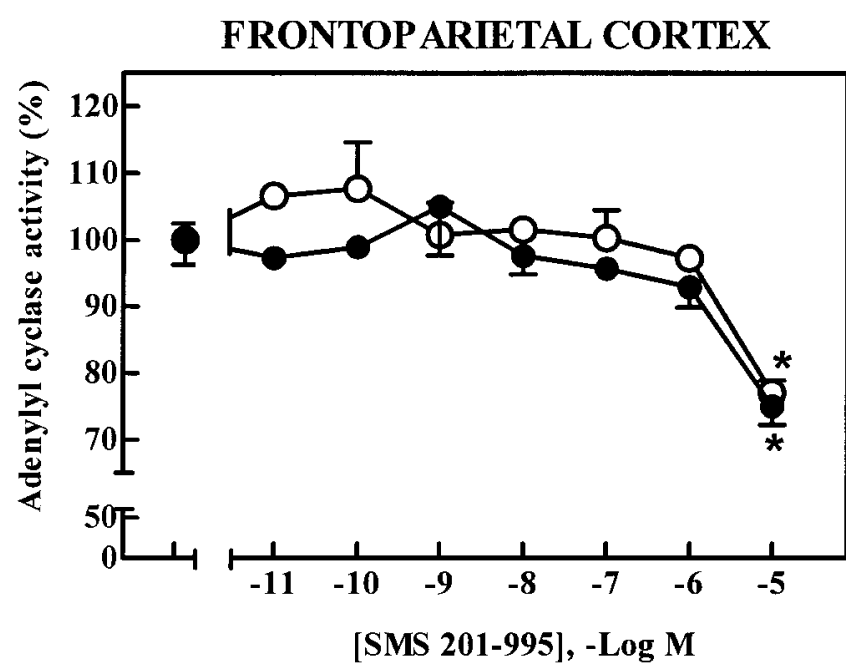

Fig. 3. Effect of increasing concentrations of SMS 201-995 on basal (open circles) and forskolin-stimulated (solid circles) adenylyl cyclase activity in rat frontoparietal cortical membranes. The effect of SMS 201-995 was studied in the absence or presence of $10^{-5} \mathrm{M}$ forskolin and the indicated concentrations of SMS 201-995. Data are expressed as a percentage of the basal or forskolin-stimulated adenylyl cyclase activity in the absence of SMS 201-995 (100\%). The results are given as the mean \pm SEM of five separated determination, each performed in duplicate. Statistical comparison vs. adenylyl cyclase activity in the absence of SMS 201-995: ${ }^{\star} P<0.05$.

only for the maximal dose tested $\left(10^{-5} \mathrm{M}\right.$; Fig. 3). Because the SMS 201-995 concentration necessary to achieved inhibition of AC activity was $10^{-5} \mathrm{M}$, this concentration was used in a subsequent detailed study of basal and FK-stimulated AC activity in control rats and rats treated with SKF 38393 or bromocriptine. The effect of SKF 38393 or bromocriptine on basal and FK-stimulated AC activity was markedly increased or decreased, respectively, in frontoparietal cortical membranes compared to controls (Table III). In the SKF 38393 or bromocriptine groups, the degree of SMS 201-995-mediated enzyme inhibition of both basal and FK-stimulated AC activity was significantly higher than in the control groups. This SMS 201- 
TABLE III. Effect of SMS 201-995 $\left(10^{-5} \mathrm{M}\right)$ and Forskolin $\left(10^{-5} \mathrm{M}\right)$ on Brain Adenylyl Cyclase (AC) Activity in Frontoparietal Cortical Membranes From Control Rats and Rats Treated With SKF 38393 (4 mg/kg, i.p.) or Bromocriptine (2 mg/kg, i.p.) 3 hr After Its Administration ${ }^{\dagger}$

\begin{tabular}{|c|c|c|c|c|}
\hline & \multicolumn{4}{|c|}{ AC activity ( $\mathrm{pmol}$ of $\mathrm{cAMP} / \mathrm{min} / \mathrm{mg}$ protein) } \\
\hline Basal activity & $152 \pm 13$ & $205 \pm 18^{\star}$ & $160 \pm 10$ & $116 \pm 14^{\star}$ \\
\hline$+10^{-5}$ M FK activity & $471 \pm 29$ & $656 \pm 25^{\star \star}$ & $464 \pm 24$ & $384 \pm 18 \star$ \\
\hline Percentage SMS 201-995 inhibition of basal & $23 \pm 3$ & $34 \pm 3^{\star}$ & $20 \pm 3$ & $32 \pm 4^{\star}$ \\
\hline -Fold FK stimulation over basal & $3.1 \pm 0.3$ & $3.2 \pm 0.4$ & $2.9 \pm 0.2$ & $3.0 \pm 0.3$ \\
\hline
\end{tabular}

${ }^{\dagger}$ Data are the mean \pm SEM of five separate experiments, each performed in duplicate.

$\star P<0.5$ vs. control.

$\star \star P<0.01$ vs. control.

$\star \star \star P<0.001$ vs. control.

\section{Frontoparietal cortex}

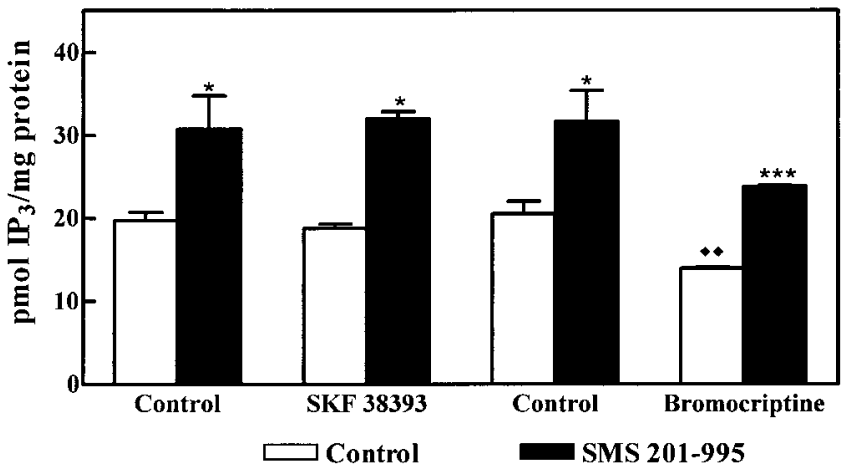

Fig. 4. Comparison of the ability of the somatostatin analogue SMS 201-995 to accumulate $\mathrm{IP}_{3}$ in frontoparietal cortical slices of control, SKF 38393 (4 mg/kg, i.p.)-treated, and bromocriptine $(2 \mathrm{mg} / \mathrm{kg}$, i.p.)-treated rats. Frontoparietal cortical slices were incubated for $15 \mathrm{sec}$ at $37^{\circ} \mathrm{C}$ with $10^{-7} \mathrm{M}$ of SMS 201-995. Values are expressed as the mean \pm SEM of five separate experiments. Statistical comparison vs. basal: ${ }^{\star} P<0.05 ; \star \star \star x P<0.001$. Statistical comparison between basals: double diamonds, $P<0.01$.

995 effect was significantly higher in the SKF 38393treated animals than in the bromocriptine-treated animals (Table III). To test whether the observed changes were related to modifications in AC expression, we measured the response of the enzyme to the diterpene FK, which is assumed to act directly on the catalytic subunit. No significant differences were detected in the -fold FK stimulation over basal AC activity between the controls and the SKF 38393- or bromocriptine-treated group.

The treatment with SKF 38393 did not modify basal $\mathrm{IP}_{3}$ levels, whereas bromocriptine decreased $\mathrm{IP}_{3}$ accumulation in frontoparietal cortical slices (Fig. 4). SMS 201995 significantly increased $\mathrm{IP}_{3}$ accumulation in frontoparietal cortical slices from control, SKF 38393- and bromocriptine-treated rats (Fig. 4).

\section{DISCUSSION}

\section{SKF 38393 and Bromocriptine Increased the Number of SRIF Receptors}

The data reported here suggest that D1- and D2receptors are involved in the increase of functional SRIF receptors in the rat frontoparietal cortex. This was manifested by an increase in the ability of SMS 201-995 to inhibit FK-stimulated AC activity in the rats treated with SKF 38393 or bromocriptine. The fact that SKF 38393 and bromocriptine increase the functional activity of SRIF receptors seems to be a result of activation of D1 and D2 receptors, respectively, in that the effect of SKF 38393 on SRIF binding was effectively antagonized by the D1specific antagonist SCH 23390, whereas the effect of bromocriptine was abolished by the D2-specific antagonist raclopride. Furthermore, the in vitro addition of the D1 or D2 DA agonist, SKF 38393 or bromocriptine, respectively, to frontoparietal cortical membranes from untreated rats did not affect the SRIF binding parameters. The present result is in agreement with the result that the blockage of dopaminergic transmission with haloperidol (3 days) did not affect the number of SRIF receptors in rat brain (Pérez-Oso et al., 1989). The mechanism by which dopaminergic stimulation increases $\left[{ }^{125} \mathrm{I}\right] \mathrm{Tyr}^{3}$ octreotide binding in the frontoparietal cortex is not clear. It has been demonstrated that sulpiride increases dopaminergic neurotransmision (Elliot et al., 1977). Our research group has demonstrated that sulpiride significantly decreased the SRIF-like immunoreactivity levels in the frontoparietal cortex (Rodríguez-Sánchez et al., 1994). Therefore, the decrease in the SRIF-like immunoreactivity content could explain the increase in Bmax observed. On the other hand, it is unknown whether this increase in Bmax is secondary to that of the dopaminergic agonists on other neurotransmitter systems.

\section{Effects of SKF 38393 and Bromocriptine on AC Activity}

Stimulation of D1 receptors activates AC, whereas D2 receptor stimulation either inhibits or does not stim- 
ulate the activity of this enzyme (Kebabian et al., 1984; Battaglia et al., 1985; Onali et al., 1985; Weiss et al., 1985). Therefore, our results seem to be in agreement with the above-mentioned studies. The -fold FK stimulation of AC activity over basal activity was similar in frontoparietal cortical membranes of control and SKF 38393- or bromocriptine-treated rats, indicating that the AC catalytic subunit was intact.

Basal and FK-stimulated AC activity was inhibited by SMS 201-995 in all experimental groups analyzed, which is in agreement with other authors (Markstein et al., 1989). A concentration of $10^{-5} \mathrm{M}$ of SMS 201-995 was required to produce this inhibition. A concentration of $10^{-4} \mathrm{M}$ of SRIF was used by other authors in their studies on the effect of SRIF on AC activity in rat and human brain (Schettini, 1991). The high affinity of the SRIF receptors is incompatible with the SRIF concentration required to reduce $\mathrm{AC}$ activity. In view of the different response of neuronal and glial cells to SRIF-mediated inhibition of AC (Chneiweiss et al., 1985a,b; Colás et al., 1992), it is possible that the cell heterogeneity of the present preparations is responsible for the high SMS 201995 concentration necessary to achieve AC inhibition. In addition, the synaptic SRIF concentration is, so far, unknown. SMS 201-995-mediated inhibition of basal and FK-stimulated AC activity was greater in rats treated with SKF 38393 or bromocriptine than in the control animals. This increased AC sensitivity to SMS 201-995 induced by both dopaminergic agonists may be a consequence of the rise in the number of SRIF receptor observed.

\section{Effects of SKF 38393 and Bromocriptine on $\mathrm{IP}_{3}$}

Our results showing that D1-like DA receptor stimulation had no effect on $\mathrm{IP}_{3}$ formation, whereas stimulation of D2-like DA receptors decreased the $\mathrm{IP}_{3}$ formation, are in agreement with previous studies (Pizzi et al., 1988). However, there are many contradictory reports in the literature regarding the effects of D1 DA receptors on inositol phosphate metabolism. Studies in anterior pituitary cells also suggest that D2 receptor stimulation indirectly suppresses inositol phospholipid hydrolysis (Simmonds and Strange, 1985; Journot et al., 1987). However, Kelly et al. (1988) were unable to observe activation or inhibition of striatal phosphoinositide metabolism with either DA or selective D1 and D2 DA receptor agonists. The discrepancy between our findings and the earlier reports possibly stems from differences in the drug dose used and the time points at which the observations were made. SMS 201-995 significantly increased $\mathrm{IP}_{3}$ accumulation in frontoparietal cortical slices of control rats in agreement with other studies (Lachowicz et al., 1994; Muñoz-Acedo et al., 1995). The SMS 201-995 concentration eliciting $\mathrm{IP}_{3}$ accumulation was about two orders of magnitude higher than the corresponding binding. This apparent discrepancy can be explained by the different experimental conditions used in each type of experiment. Our binding studies were obtained at equilibrium after an incubation of $90 \mathrm{~min}$ at $25^{\circ} \mathrm{C}$. In contrast, $\mathrm{IP}_{3}$ accumulation is a transient process that must be measured $15 \mathrm{sec}$ after exposing brain slices to SRIF. Therefore, this very short period may not be sufficient to reach binding equilibrium.

The dopamine agonists SKF 38393 and bromocriptine enhance the ability of SMS 201-995 to inhibit basal and FK-stimulated cAMP accumulation. However, no differences in SMS 201-995-stimulated phosphoinositides turnover were detected. Previous studies have demonstrated uncoupling of receptors from $G$ proteins. In this regard, Ungar et al. (1993) have demonstrated that estrogen uncouples $\beta$-adrenergic receptor from the $G$ protein. Therefore, the differences found between the SMS 201995-induced inhibition of cAMP accumulation and the SMS 201-995-induced stimulation of $\mathrm{IP}_{3}$ accumulation could be due to an uncoupling of the receptor from $\mathrm{Gq}$ proteins and/or PLC.

The dopaminergic input to the frontal cortex has an important role in motor and cognitive functions (Gaspar et al., 1995). These effects are mediated by both D1 and D2 DA receptors (Civelli et al., 1993). In caudate putamen, nucleus accumbens, olfactory tubercle, substantia nigra, entopeduncular nucleus, zona incerta, and region of the ventral internal capsule, D1 receptor subtype was found at greater density than D2 receptor subtypes. In the olfactory nerve layer, a higher density of D2 receptor sybtypes was found in comparison to D1 receptor subtype. In the ventral tegmental area, the presence of D2 receptor subtype was not detected (Boyson et al., 1986). Moderate densities of mRNA D1 receptor sites are seen in deep layers of the frontal and parietal cortices, with light diffuse labeling observed in more superficial layers (Mansour et al., 1990). Dense levels of D2 receptor mRNA are found in the layer I and in layers II and III of the frontal and parietal cortices. However, the deeper layers (V and VI) of frontal and parietal cortices show moderate to low levels of D2 receptor mRNA (Mansour et al., 1990). D1 and D2 receptors have been described in different populations of efferent pyramidal neurons in the rat frontal cortex (Mansour et al., 1990; Mansour and Watson, 1995). The expression of D1 and D2 receptor genes is specific for different categories of pyramidal neurons (Gaspar et al., 1995). Recently, the presence of SSTR1, SSTR2, SSTR 3, and SSTR 5 receptors in deep layers of frontal and parietal cortex has been demonstrated (Bruno et al., 1993; Kong et al., 1994; Pérez and Hoyer, 1995). In addition, the expression of mRNA for SRIF receptor subtypes SSTR2 and SSTR 3 has been found on pyramidal cells in the cited brain areas (Kong et al., 1994; Pérez and Hoyer, 1995). The confirmed presence of DA terminals (Descarries et al., 1987) and SRIF interneurons (Finley et al., 1981; Johansson et al., 1984) with its specific receptors (Mansour et al., 1990; Bruno et al., 1993; Kong et al., 1994; Mansour and Watson, 1995; Pérez and Hoyer, 1995) in the deepest layer of the frontal motor areas and parietal somatosensory areas implies a role in the processing sensoriomotor information (Welker, 1971; Gaspar et al., 1995). Taken together, the present results support the notion that the dopaminergic system regulates the binding 
of SRIF to its specific receptors in the rat frontoparietal cortex.

\section{ACKNOWLEDGMENTS}

We thank Martin Lexell from Centro de Lenguas Extranjeras of the Universidad de Alcalá, Angela Martín Espinosa for her excellent technical assistance, and Lilian Puebla and Jerry Keller for their linguistic assistance. We express our sincere thanks to Astra Ifesa (Barcelona, Spain) for the supply of raclopride and to Sandoz (Basel, Switzerland) for the supply of SMS 201-995 and SDZ 204090 .

\section{REFERENCES}

Antoniotti H, Fagot-Revurat P, Esteve J-P, Fourmy D, Pradayrol L, Ribet A. 1984. Purification of radioiodinated somatostatin-related peptides by reversed-phase high-performance liquid chromatography. J Chromatogr 296:181-188.

Augood SJ, Kiyama H, Faull RLM, Emson PC. 1991. Dopaminergic $D_{1}$ and $\mathrm{D}_{2}$ receptor antagonists decrease prosomatostatin mRNA expression in rat striatum. Neuroscience 44:35-44.

Battaglia C, Norman AB, Hess EJ, Creese I. 1985. D 2 dopamine receptormediated inhibition of forskolin-stimulated adenylate cyclase activity in rat striatum. Neurosci Lett 59:177-182.

Boyson SJ, McGonigle P, Molinoff PB. 1986. Quantitative autoradiographic localization of the $\mathrm{D}_{1}$ and $\mathrm{D}_{2}$ subtypes of dopamine receptors in rat brain. J Neurosci 6:3177-3188.

Bredt DS, Mourey RJ, Snyder SH. 1989. A simple, sensitive, and specific radioreceptor assay for inositol-1,4,5-trisphosphate in biological tissues. Biochem Biophys Res Commun 3:976-982.

Brunns C, Weckbecker G, Raulf F, Lübbert H, Hoyer D. 1995. Characterization of somatostatin receptor subtypes. In: Somatostatin and its receptors (Ciba Foundation Symposium 190). Chichester: John Wiley and Sons. p 89-110.

Bruno JF, Xu Y, Song J, Berelowitz M. 1993. Tissue distribution of somatostatin receptor subtype messenger ribonucleic acid in the rat. Endocrinology 133:2561-2567.

Challiss RAJ, Batty I, Nahorski SR. 1988. Mass measurements of inositol $(1,4,5)$ trisphosphate in rat cerebral cortex slices using a radioreceptor assay: effects of neurotransmitters and depolarization. Biochem Biophys Res Commun 157:684-691.

Chneiweiss H, Glowinski J, Premont J. 1985a. Modulation by monoamines of somatostatin-sensitive adenylate cyclase on neuronal and glial cells from the mouse brain in primary cultures. J Neurochem 44:1825-1831.

Chneiweiss H, Glowinski J, Premont J. 1985b. Vasoactive intestinal polypeptide receptors linked to an adenylate cyclase and their relationship with biogenic amine and somatostatin-sensitive adenylate cyclase on central neuronal and glial cells in primary cultures. J Neurochem 44:779786.

Civelli O, Bunzow JR, Grandy DK. 1993. Molecular diversity of the dopamine receptors. Annu Rev Pharmacol Toxicol 32:281-307.

Colás B, Arilla E, Prieto JC. 1992. Somatostatin binding to a fresh rat astrocyte-enriched suspension. Neuropeptides 23:1-17.

Czernik AJ, Petrack V. 1983. Somatostatin receptor binding in rat cerebral cortex. Characterization using a nonreducible somatostatin analog. J Biol Chem 285:5525-5530.

De los Frailes MT, Cacicedo L, Lorenzo MJ, Tolón RM, Fernández G, Sánchez-Franco F. 1993. Neurotransmitter regulation of somatostatin secretion by fetal rat cerebral cortical cells in culture. J Endocrinol Invest 16:661-668.

Descarries L, Lemay B, Doucet G, Berger B. 1987. Regional and laminar density of the dopamine innervation in adult rat cerebral cortex. Neuroscience 21:807-824.
Elliot PN, Jenner P, Huizing G, Marsden CD, Miller R. 1977. Substituted benzamides as cerebral dopamine antagonists in rodents. Neuropharmacology 16:333-342.

Engber TM, Boldry RC, Kuo S, Chase TN. 1992. Dopaminergic modulation of striatal neuropeptides: differential effects of $D_{1}$ and $D_{2}$ receptor stimulation on somatostatin, neuropeptide $\mathrm{Y}$, neurotensin, dynorphin and enkephalin. Brain Res 581:261-268.

Epelbaum J, Tapia-Arancibia L, Kordon C, Enjalbert A. 1982. Characterization, regional distribution and subcellular distribution of ${ }^{125} \mathrm{I}_{-} \mathrm{Tyr}^{1}$ somatostatin binding sites in rat brain. J Neurochem 38:1515-1523.

Finley JCW, Maderdrutt JL, Roger LJ, Petrusz P. 1981. The immunocytochemical localization of somatostatin-containing neurons in the rat central nervous system. Neuroscience 6:2173-2192.

Gaspar P, Bloch B, Le-moine C. 1995. $\mathrm{D}_{1}$ and $\mathrm{D}_{2}$ receptor gene expression in the rat frontal cortex: cellular localization in different classes of efferent neurons. Eur J Neurosci 7:1050-1063.

Gilman AG. 1970. A protein binding assay for adenosine $3^{\prime} 5^{\prime}$-cyclic monophosphate. Proc Natl Acad Sci USA 67:305-312.

Glowinski J, Iversen LL. 1966. Regional studies of catecholamines in the rat brain. I. The disposition of $\left[{ }^{3} \mathrm{H}\right]$ norepinephrine, $\left[{ }^{3} \mathrm{H}\right]$ dopamine and $\left[{ }^{3} \mathrm{H}\right]$ DOPA in various regions of the brain. J Neurochem 13:655-669.

Hendry SHC, Jones EG, Emson PC. 1984. Morphology, distribution and synaptic relations of somatostatin- and neuropeptide $\mathrm{Y}$-immunoreactive neurons in rat and monkey neocortex. J Neurosci 4:2497-2517.

Houslay MD, Metcalfe JC, Warren GB, Hesketh TR, Smith GA. 1976. The glucagon receptor of rat liver plasma membrane can couple to adenylate cyclase without activating it. Biochim Biophys Acta 436:489494.

Hoyer D, Lübbert H, Bruns C. 1994. Molecular pharmacology of somatostatin receptors. Naunyn-Schmiedebergs Arch Pharmacol 350:441453.

Hoyer D, Bell GI, Berelowitz M, Epelbaum J, Feniuk W, Humphrey PPA, O'Carroll A-M, Patel YC, Schonbrunn A, Taylor JE, Reisine T. 1995. Classification and nomenclature of somatostatin receptors. Trends Pharmacol Sci 16:86-88

Johansson O, Hokfelt T, Elde RP. 1984. Immunohistochemical distribution of somatostatin-like immunoreactivity in the central nervous system of the adult rat. Neuroscience 13:265-339.

Journot L, Homburger V, Pantaloni C, Priam M, Bockaert J, Enjalbert A. 1987. An islet activating protein-sensitive $G$ protein is involved in dopamine inhibition of angiotensin and thyrotropyn-releasing hormonestimulated inositol phosphate production in anterior pituitary cells. J Biol Chem 262:15106-15110.

Kebabian JW, Beaulieu M, Itoh Y. 1984. Pharmacological and biochemical evidence for the existence of two categories of dopamine receptor. Can J Neurol Sci 11:114-117.

Kelly E, Batty I, Nahorski SR. 1988. Dopamine receptor stimulation does not affect phosphoinositide hydrolysis in slices of rat striatum. J Neurochem 51:918-924.

Kong H, DePaoli AM, Breder CD, Yosuda K, Bell GI, Reisine T. 1994. Differential expression of messenger RNAs for somatostatin receptor subtypes SSTR1, SSTR2 and SSTR 3 in adult rat brain: analysis by RNA blotting and in situ hybridization histochemistry. Neuroscience 59:175184.

Krantic S, Martel JC, Weismann D, Pujol JF, Quirion R. 1990. Quantitative autoradiographic study of somatostatin receptors heterogeneity in the rat extrahypothalamic brain. Neuroscience 39:127-137.

Krantic S, Robitaille Y, Quirion R. 1992. Deficits in the somatostatin $\mathrm{SS}_{1}$ receptor sub-type in frontal and temporal cortices in Alzheimer's disease. Brain Res 573:299-304.

Lachowicz A, Pawlikowski M, Ochedalski T. 1994. Somatostatin-14 increases the inositol-1,4,5-trisphosphate content in various areas of the brain. Biochem Biophys Res Commun 203:379-384. 
Law SF, Manning D, Reisine T. 1991. Identification of the subunits of GTP-binding proteins coupled to somatostatin receptors. J Biol Chem 266:17885-17897.

Lee N, Radke JM, Vincent SR. 1988. Intracerebral cysteamine infusions attenuate the motor response to dopaminergic agonists. Behav Brain Res 29:179-183.

Lowry OH, Rosenbrough NJ, Farr AL, Randall RJ. 1951. Protein measurement with the Folin phenol reagent. J Biol Chem 193:265-275.

Mansour A, Watson SJ Jr. 1995. Dopamine receptor expression in the central nervous system. In: Bloom FE, Kupfler DJ, editors. Psychopharmacology: the fourth generation of progress. New York: Raven Press, Ltd. p 207-219.

Mansour A, Meador-WoodruffJH, Bunzow JR, Civelli O, Akil H, Watson SJ. 1990. Localization of dopamine $\mathrm{D}_{2}$ receptor $m R N A$ and $\mathrm{D}_{1}$ and $\mathrm{D}_{2}$ receptor binding in rat brain and pituitary: an in situ hybridisationreceptor autoradiography analysis. J Neurosci 10:2587-2600.

Markstein R, Stockli KA, Reubi JC. 1989. Differential effects of somatostatin on adenylate cyclase as functional correlate for different brain somatostatin receptor subpopulations. Neurosci Lett 104:13-18.

Munson PJ, Rodbard D. 1980. A versatile computerized approach for characterization of ligand binding systems. Anal Biochem 107:220-239.

Muñoz-Acedo G, Izquierdo-Claros RM, Sánchez-Alonso JA, del Hoyo N, Pérez-Albarsanz MA, Arilla E. 1995. Effect of somatostatin on the mass accumulation of inositol-1,4,5-trisphosphate in rat hypothalamus, striatum, frontoparietal cortex and hippocampus. Neurosci Lett 197:41-44.

Onali P, Olianas M, Gessa GL. 1985. Characterization of dopamine receptors mediating inhibition of adenylyl cyclase activity in rat striatum. Mol Pharmacol 28:138-145.

Patel YC. 1999. Somatostatin and its receptor family. Frontiers Neuroendocrinol 20:157-198.

Pérez-Oso E, Arilla E. 1993. Effect of prenatal dopamine receptor blocking on somatostatin receptor binding in the developing rat brain. Brain Res 31:165-169.

Pérez-Oso E, Colás B, López-Ruiz MP, Arilla E. 1989. Long-term haloperidol treatment decreases somatostatin binding in the rat brain. Neuropeptides 13:157-163.

Pérez J, Hoyer D. 1995. Co-expression of somatostatin SSTR-3 and SSTR-4 receptor messenger RNAs in the rat brain. Neuroscience 64: 241-253.

Pizzi M, Da Prada M, Valerio A, Memo A, Spano P, Haefely WE. 1988. Dopamine $\mathrm{D}_{2}$ receptor stimulation inhibits inositol phosphate generating system in rat striatal slices. Brain Res 456:235-240.
Reubi JC. 1985. New specific radioligand for one subpopulation of brain somatostatin receptors. Life Sci 36:1829-1836.

Reubi JC, Maurer R. 1985. Autoradiographic mapping of somatostatin receptors in the rat central nervous system and pituitary. Neuroscience 15:1183-1193.

Rodríguez-Sánchez MN, Boyano-Adánez MC, Puebla L, RodríguezHenche N, Guijarro LG, Prieto JC, Arilla E. 1994. Effect of sulpiride on somatostatin receptors, somatostatin-like inmunoreactivity and modulation of adenylyl cyclase activity in the rat brain. Neuropharmacology 33:745-754.

Rodríguez-Sánchez MN, Puebla L, López-Sañudo S, Rodríguez-Martín E, Martínez-Espinosa A, Rodríguez-Pena MS, Juarranz MG, Arilla E. 1997. Dopamine enhances somatostatin receptor-mediated inhibition of adenylate cyclase in rat striatum and hippocampus. J Neurosci Res 48:238-248.

Salin P, Mercugliano M, Chesselet MF. 1990. Differential effects of chronic treatment with haloperidol and clozapine on the level of preprosomatostatin mRNA in the striatum, nucleus accumbens, and frontal cortex. Cell Mol Neurobiol 10:127-143.

Scatchard G. 1949. The attractions of proteins for small molecules and ions. Ann NY Acad Sci 51:660-671.

Schettini G. 1991. Brain somatostatin: receptor-coupled transducing mechanisms and role in cognitive functions. Pharmacol Res 23:203-215.

Shogmonian JJ, Chesselet MF. 1991. Lesions of dopaminergic nigrostriatal pathway alter preprosomatostatin messenger RNA levels in the striatum, the entopeduncular nucleus and the lateral hypothalamus of the rata. Neuroscience 42:49-59.

Simmonds SH, Strange PG. 1985. Inhibition of inositol phospholipid breackdown by $\mathrm{D}_{2}$ dopamine receptors in dissociated bovine anterior pituitary cells. Neurosci Lett 60:267-272.

Srikant CB, Patel YC. 1981. Somatostatin receptors: identification and characterization in rat brain membranes. Proc Natl Acad Sci USA 78: 3930-3934

Ungar S, Makman MH, Morris SA, Etgen AM. 1993. Estrogen uncouples beta-adrenergic receptor from the stimulatory guanine nucleotidebinding protein in female rat hypothalamus. Endocrinology 133:28182826.

Weiss S, Serben M, García-Sáinz JA, Bockaert J. 1985. D2-dopamine receptor mediated inhibition of cyclic AMP formation in striatal neurons in primary culture. Mol Pharmacol 27:595-599.

Welker C. 1971. Microelectrode delineation of fine grain somatotropic organization of SmI cerebral neocortex in albino rat. Brain Res 26:259 275. 